九州大学学術情報リポジトリ

Kyushu University Institutional Repository

\title{
Comparison of Solid-State Glycation of Whey Proteins through Maillard Reaction between Microwave and Conductive Heating
}

Noma, Se i j i

Laboratory of Food Process Engineering, Division of Bioresources and Bioenvironmental Sciences, Faculty of Agriculture, Kyushu University

Sumikawa, Masanori

Laboratory of Food Process Engineering, Division of Bioresources and Bioenvironmental Sciences, Faculty of Agriculture, Kyushu University

Tsubokura, Yasuhiro

Laboratory of Food Process Engineering, Division of Bioresources and Bioenvironmental Sciences, Faculty of Agriculture, Kyushu University

Inoue, Tatsunor $\mathrm{i}$

Laboratory of Food Process Engineering, Division of Bioresources and Bioenvironmental Sciences, Faculty of Agriculture, Kyushu University

他

https://doi.org/10.5109/14058

出版情報：九州大学大学院農学研究院紀要. 54 (1)，pp. 191-194，2009-02-27. Faculty of Agriculture, Kyushu University

バージョン :

権利関係 : 


\title{
Comparison of Solid-State Glycation of Whey Proteins through Maillard Reaction between Microwave and Conductive Heating
}

\author{
Seiji NOMA ${ }^{1}$, Masanori SUMIKAWA ${ }^{2}$, Yasuhiro TSUBOKURA ${ }^{3}$, Tatsunori INOUE ${ }^{3}$, \\ Mika TOMOZANE ${ }^{2}$, Noriyuki IGURA ${ }^{1}$ and Mitsuya SHIMODA ${ }^{1}$
}

\author{
Laboratory of Food Process Engineering, Division of Bioresources and Bioenvironmental \\ Sciences, Faculty of Agriculture, Kyushu University, \\ Fukuoka 812-8581, Japan \\ (Received November 11, 2008 and accepted December 5, 2008)
}

\begin{abstract}
The mechanism of microwave heating $(\mathrm{MH})$, which rotates and vibrates the electric dipole of target molecules, is different from conductive heating $(\mathrm{CH})$. In the present study we compared the rate of solidstate glycation of whey proteins (WP) by glucose between $\mathrm{MH}$ and $\mathrm{CH}$. During heating for glycation temperature of WP-glucose mixture reached to 60,75 and $90^{\circ} \mathrm{C}$ at the heating time of 10 min in both treatments. No significant difference $(\mathrm{p}>0.05)$ was observed in the rate of glycation of WP between $\mathrm{MH}$ and $\mathrm{CH}$ when estimated by molecular mass of glycated WP through SDS-PAGE analysis and by glycation ratio of primary amino groups in $\beta$-lactoglobulin using $o$-phthalaldehyde. The results of this study suggest that characteristic heating mechanism of $\mathrm{MH}$ does not affect glycation rate of WP in solid-state.
\end{abstract}

\section{INTRODUCTION}

Whey proteins (WP) represent a rich and varied mixture of secreted proteins with wide-ranging chemical, physical and functional properties (Chevalier et al., 2001). Due to these beneficial functional properties, WP are used as ingredients in many industrial food products (Chevalier et al., 2001; Alomirah and Alli., 2004; Castaño et al., 2005). However, $\beta-\mathrm{LG}$, a dominant protein of WP, is a potent allergen of milk allergy; $~ 82 \%$ of milk allergy patients are sensitive to $\beta-\mathrm{LG}$ (Spies, 1973).

Maillard reaction is the most frequent reaction in food products, because this reaction is catalyzed by just only heating. Maillard reaction is started by the formation of a Schiff base between carbonyl group of reducing sugars and amino groups of amino acids, peptide and protein. The formed Schiff base gives the Amadori product through rearrangements (Mennella, et al., 2006). It was confirmed that the glycation of WP through Maillard reaction improved solubility (Castaño et al., 2005; Enomoto et al., 2007), heat stability (Broersen et al., 2004; Chevalier et al., 2001), emulsifying properties (Broersen et al., 2004; Chevalier et al., 2001) and decreased in antigenicity (Enomoto et al., 2007; Hattori et al., 2004). Therefore modification of WP through Maillard reaction can promote utilization of WP in the food industry.

Microwave heating $(\mathrm{MH})$ is a safe and rapid heating method already used to heating and drying of foods. MH has a different heating mechanism from conductive heating $(\mathrm{CH})$. Microwave rotates and vibrates the electric dipole of target molecules, and that is preferentially

\footnotetext{
Graduate School of Bioresource and Bioenvironmental Sciences, Kyushu University

Faculty of Agriculture, Kyusyu University

Division of Bioresources and Bioenvironmental Sciences, Kyushu University

* Corresponding author (E-mail: mshimoda@agr.kyushu-u. ac.jp)
}

absorbed by water molecules. The characteristic heating mechanism of $\mathrm{MH}$ can affect the rate of Maillard reaction. Research effort has been directed to determine whether MH has any non-thermal effect on the rate of Maillard reaction. Guan et al. (2006) described that $\mathrm{MH}$ accelerated the Maillard reaction of soy protein isolate with sugars compared to CH. Shazman et al. (2007) described that $\mathrm{MH}$ failed to show any significant effect on glycation of glycine by glucose. However Maillard reaction in these studies was performed in water or a buffer solution. It is considered that microwave directly heated water molecules and those water molecules indirectly heated target molecules. To assess the effect of characteristic heating mechanism of microwave on Maillard reaction, $\mathrm{MH}$ is required to be done on dry protein powder. In addition, Guan et al. (2006) paid no attention to standardize heating profile between $\mathrm{MH}$ and $\mathrm{CH}$. Temperature is the most important parameters that affect the Maillard reaction (O'Brien, 1995). This suggests that comparison of Maillard reaction between $\mathrm{MH}$ and $\mathrm{CH}$ requires standardization of their heating profiles.

In the present study, the rate of solid-state glycation of WP by glucose was compared between $\mathrm{MH}$ and $\mathrm{CH}$ under standardized heating profiles.

\section{MATERIALS AND METHODS}

\section{Glycation of whey proteins by microwave and con- ductive heating}

Whey proteins (WP) were kindly donated by Snow Brand Milk Products (Tokyo, Japan). WP and glucose (Nacalai tesque, Kyoto, Japan) were mixed at a weight ratio of 3.4:1 and dissolved into distilled water, followed by lyophilization. The moisture content of this powder was about $6.6 \%$ when estimated by drying at $102{ }^{\circ} \mathrm{C}$ under atmospheric pressure. The resultant powder was ground in a mortar and subjected to MH (IMCR-25003 Model, 400W full power, IDX Co., Kanagawa, Japan) or CH (TGradient Thermoblock, Biometra, Germany). 
Temperature change of the sample powder during $\mathrm{MH}$ was monitored by a thermocouple directly inserted into the sample powder.

\section{SDS-PAGE}

Glycated WP formed after $\mathrm{MH}$ or $\mathrm{CH}$ was analyzed by SDS-PAGE under reducing condition by the method of Laemmli (1970) using 15\% acrylamide gel (BIO CRAFT, Tokyo, Japan). SDS-PAGE was run at a constant current of $30 \mathrm{~mA}$. The gel was stained with coomassie brilliant blue R250.

\section{Measurement of glycation ratio \\ Separation of $\beta$-lactoglobulin}

Beta-lactoglobulin ( $\beta-\mathrm{LG}$ ) was separated from WP by a slightly modified method of Alomirah and Alli (2004). WP was dissolved into distilled water at a concentration of $0.23 \mathrm{mg} / \mathrm{ml}$ by mixing at room temperature for $30 \mathrm{~min}$ using a rotator. The soluble fraction was obtained after centrifugation at $4^{\circ} \mathrm{C}, 5000 \times \mathrm{g}$ for $30 \mathrm{~min}$ and the following filtration through $0.2 \mu \mathrm{m}$ of membrane filter. Sodium citrate was added to the resultant solution at the final concentration of $150 \mathrm{mM}$ and acidified to $\mathrm{pH} 3.9$ with $6 \mathrm{M}$ citric acid. After the incubation at $35^{\circ} \mathrm{C}$ for $45 \mathrm{~min}$, the solution was centrifuged at $4^{\circ} \mathrm{C}, 5000 \times$ g for $30 \mathrm{~min}$, and the supernatant was carefully transferred to the other tube. Sodium chloride was added to the supernatant to give a concentration of $7 \%(\mathrm{w} / \mathrm{v})$ and centrifuged at $4{ }^{\circ} \mathrm{C}, 5000 \times$ g for $30 \mathrm{~min}$, and the same weight of $\mathrm{NaCl}$ was added again to the resultant supernatant. After centrifugation at $4{ }^{\circ} \mathrm{C}, 5000 \times \mathrm{g}$ for $30 \mathrm{~min}$, the supernatant was recovered, followed by desalting using Vivaspin filter unit with a 10,000 molecular mass cut-off membrane (Sartorius, Germany). The resulting solution was used as $\beta$-LG solution. The separation of $\beta$-LG was validated by western blotting. Briefly, the separated $\beta$-LG solution was subjected to SDS-PAGE as the same method described above and electroblotted onto PVDF membrane using semi-dry blotter NA-1512 (Nihon Eido, Tokyo, Japan) at a constant current of $200 \mathrm{~mA}$. Primary and secondary antibody used was rabbit anti $\beta$-LG polyclonal antibody and avidin-coupled anti rabbit Ig polyclonal antibody, respectively.

Determination of glycation ratio of $\beta-L G$

The glycation ratio was determined by measuring glycated primary amino groups in $\beta$-LG using $O$-phthaldialdehyde (OPA) by the method of Church et al. (1983). A hundred $\mu$ l of the solution of glycated WP formed by $\mathrm{CH}$ or $\mathrm{MH}$ was added to $2 \mathrm{ml}$ of OPA reagent, which was prepared just before use by mixing $40 \mathrm{mg}$ of OPA (dissolved in $1 \mathrm{ml}$ of methanol), $25 \mathrm{ml}$ of $100 \mathrm{mM}$ sodium tetraborate, $2.5 \mathrm{ml}$ of $20 \%$ (w/w) sodium dodecyl sulfate (SDS) and $100 \mu \mathrm{l}$ of $\beta$-mercaptoethanol, and then diluting to a final volume of $50 \mathrm{ml}$ with distilled water. The solution was mixed by repeated inversion and stood for 2 min at room temperature, and the absorbance was measured at $340 \mathrm{~nm}$ in a spectrophotometer (UV-1700, Shimadzu, Kyoto, Japan). Data was shown in the following equation, Glycation ratio $(\%)=\left\{1-\left(\mathrm{A}_{340}\right.\right.$ of glycated $\beta-\mathrm{LG} / \mathrm{A}_{340}$ of unglycated $\left.\left.\beta-\mathrm{LG}\right)\right\} \times 100$. Significant dif- ference in glycation ratio between $\mathrm{CH}$ and $\mathrm{MH}$ was determined Student's or Welch's t test after F test.

\section{RESULTS AND DISCUSSION}

It is expected that the characteristic heating effect of microwave on Maillard reaction is obtained when the treatment was performed against dry protein powder. In addition, it is considered that heating profile affects the Maillard reaction. Therefore in the present study we compared solid-state glycation through Maillard reaction between $\mathrm{MH}$ and $\mathrm{CH}$ under similar heating profiles.

First, temperature changes of WP-glucose powder during $\mathrm{MH}$ were monitored by a thermocouple directly inserted into the sample powder (Fig. 1). Temperature of the powder was reached to 60,75 and $90{ }^{\circ} \mathrm{C}$ in $10 \mathrm{~min}$, where microwave output power was 210,240 and $270 \mathrm{~W}$, respectively. To obtain the similar heating profiles in $\mathrm{CH}$, each temperature come-up profile of $\mathrm{MH}$ was divided to 4 or 5 parts and linear regression was made for each part (not shown). The $\mathrm{CH}$ was performed using a thermoblock, which was programmed to fit each linear regression. WP glycated after $\mathrm{MH}$ and $\mathrm{CH}$ for 10 min were used to compare the glycation ratio between $\mathrm{MH}$ and $\mathrm{CH}$.

It was reported that glycation induced the increase in the molecular weight of protein (Christine et al., 2006). Therefore WP glycated by $\mathrm{MH}$ or $\mathrm{CH}$ for $10 \mathrm{~min}$ were subjected to SDS-PAGE analysis (Fig. 2). Two major bands having presumed molecular weights of 19 and $14 \mathrm{kDa}$ were detected. At 60 and $75^{\circ} \mathrm{C}$, both $\mathrm{MH}$ and $\mathrm{CH}$ appeared to give no effect on electrophoretic mobility of these bands, suggesting that these treatment conditions were not enough to induce glycation at the detectable level in SDS-PAGE analysis. At $90^{\circ} \mathrm{C}$, both $\mathrm{MH}$ and $\mathrm{CH}$ increased molecular weight of $\mathrm{WP}$, and the degree of the increase by $\mathrm{MH}$ and $\mathrm{CH}$ appeared to be similar. These suggest that glycation rate of WP by $\mathrm{MH}$ is similar to that by $\mathrm{CH}$.

It is known that primary amino groups show high reactivity in glycation through Maillard reaction. OPA reacts with primary amines in the presence of

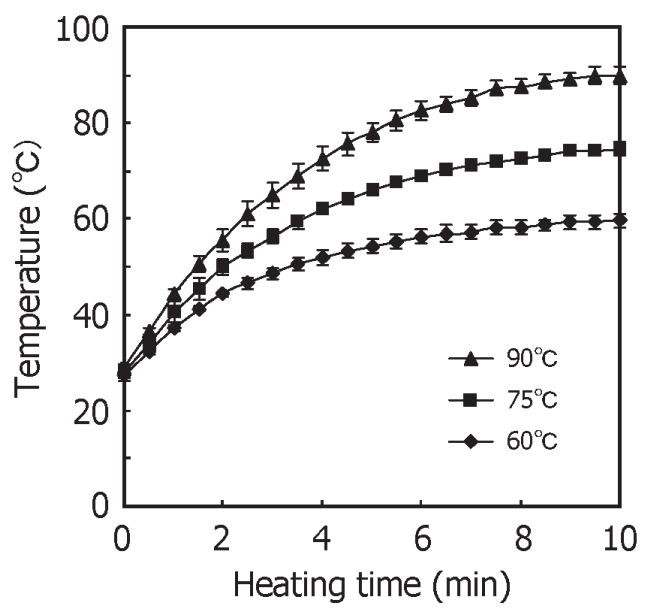

Fig. 1. Heating profiles of lyophilized WP-glucose mixture during $\mathrm{MH}$. 


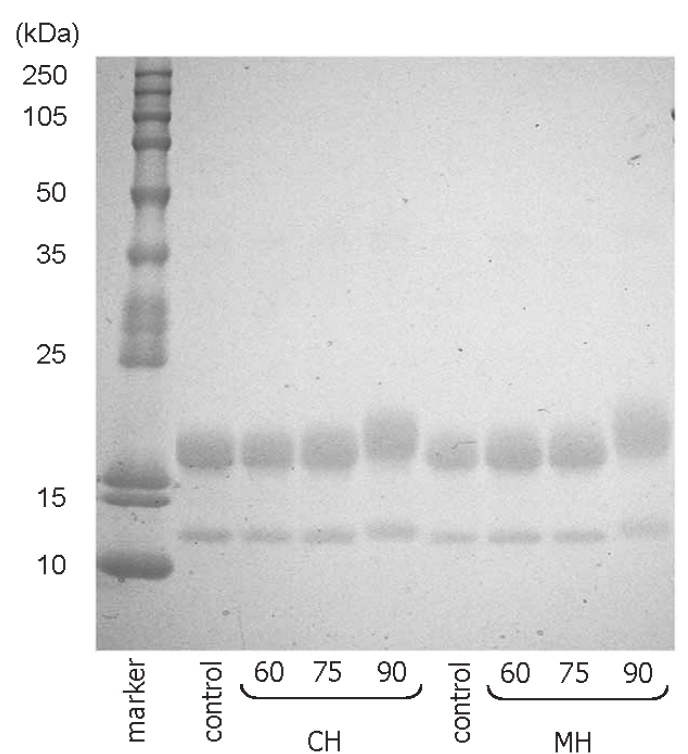

Fig. 2. SDS-PAGE of WP glycated by $\mathrm{MH}$ and $\mathrm{CH}$ at 60,75 and $90{ }^{\circ} \mathrm{C}$ for $10 \mathrm{~min}$

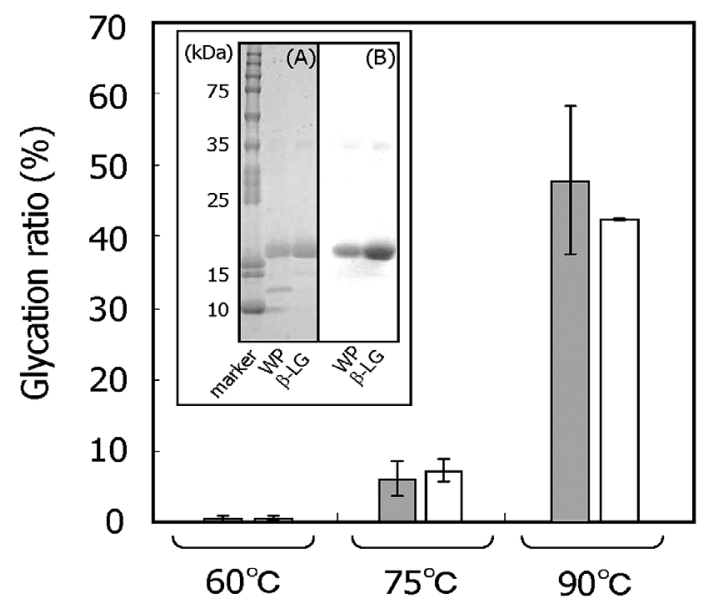

Fig. 3. Glycation ratio of $\beta-\mathrm{LG}$ after $\mathrm{MH}$ (gray) or $\mathrm{CH}$ (white) for 10 min. SDS-PAGE (A) and western blotting (B) of WP and purified $\beta-\mathrm{LG}$.

$\beta$-mercaptoethanol and SDS (Simons et al., 1976). Beta-LG is the dominant protein of WP and it is largely responsible for the physicochemical characteristics of WP, contributing to solubility, gelation, foaming, emulsification and flavour binding (Castaño et al., 2005). To obtain further quantitative data of glycation levels of WP after $\mathrm{MH}$ and $\mathrm{CH}$, we determined glycated primary amino groups of $\beta$-LG using OPA. Separation of $\beta$-LG from WP was validated by both SDS-PAGE and following western blot analysis using anti $\beta-\mathrm{LG}$ polyclonal antibody as a primary antibody. A band having a molecular weight of about $19 \mathrm{kDa}$ was observed in SDS-PAGE after the separation procedure (Fig. 3A), and that reacted with anti $\beta$-LG polyclonal antibody in western blotting (Fig. 3B). This indicated the success of $\beta-\mathrm{LG}$ separation. Fig. 3 shows the glycation ratio of WP after $\mathrm{MH}$ and $\mathrm{CH}$ at 60,75 and $90^{\circ} \mathrm{C}$ for $10 \mathrm{~min}$. Both $\mathrm{MH}$ and $\mathrm{CH}$ at $60^{\circ} \mathrm{C}$ induced about $0.5 \%$ of glycation ratio. At $75^{\circ} \mathrm{C}, \mathrm{MH}$ and $\mathrm{CH}$ induced about 6 and 7\% of glycation ratio, respec- tively. At $90^{\circ} \mathrm{C}, \mathrm{MH}$ and $\mathrm{CH}$ caused about 48 and $43 \%$ of glycation ratio, respectively. No significant difference ( $>0.05$ ) was observed between the $\mathrm{MH}$ and $\mathrm{CH}$ at all temperatures tested. These results suggest that $\mathrm{MH}$ has similar effect on glycation of $\beta-\mathrm{LG}$ compared to $\mathrm{CH}$ at the tested heating conditions. This corresponded with the results of SDS-PAGE.

In the present study, we compared the effects of $\mathrm{MH}$ and $\mathrm{CH}$ on the rate of solid-state glycation of WP under same heating profiles. MH has similar effect on glycation rate of $\mathrm{WP}$ to $\mathrm{CH}$, suggesting that $\mathrm{MH}$ has no non-thermal effect on the rate of solid-state glycation of WP. The possible parameters affecting the rate of solid-state Maillard reaction include the kind of protein and heating rate in addition to the wet or dry heating.

Further accumulation of information is required for determining whether $\mathrm{MH}$ has some effect on the glycation.

\section{REFERENCES}

Alomirah, H. F. and I. Alli 2004 Separation and characterization of $\beta$-lactoglobulin and $\beta$-lactoalbumin from whey and whey protein preparation. Int. Dairy J., 14: 411-419

Broersen, K., G.. J. Alphons, R. J. Hamer, H. J. Harmen and de Jongh 2004 Glycoforms of $\beta$-lactoglobulin with improved thermostability and preserved structural packing. Biotech. Bioeng., 86: 78-87

Castaño, L. J., R. L. Frandiño, A. Olano and M. Villamiel 2005 Study on $\beta$-lactoglobulin glycosylation with dextran: effect on solubility and heat stability. Food Chem., 93: 689-695

Chevalier, F., J. M. Chobert, Y. Popineau, M. G. Nicolas and T. Haertlé 2001 Improvement of functional properties of $\beta$-lactoglobulin glycated through the Maillard reaction is related to the nature of the sugar. Int. Dairy J., 11: 145-152

Christine, M. O., D. M. Laurence and A. S. Roger 2006 Glycation of caseinate by fructose and fructooligosaccharides during controlled heat treatment in the 'dry' state. J. Sci. Food Agri., 86: 722-731

Church, F. C., H. E. Swaisgood, D. H. Porter and G. L. Catignani 1983 Spectrophotometric assay using o-phthaldialdehyde for determination of proteolysis in milk and isolated milk proteins. J. Dairy Sci., 66: 1219-1227

Enomoto, H., C. P. Li, K. Morizane, H. R. Ibrahim, Y. Sugimoto, S. Ohki, H. Ohtomo and T. Aoki 2007 Glycation and phosphorylation of $\beta$-lactoglobulin by dry-heating: Effect on protein structure and some property. J. Agri. Food Chem., 55 $2392-2398$

Guan, J. J., A-Y. Qiu, X-Y, Liu, Y-F. Hua and Y-H. Ma 2006 Microwave improvement of soy protein isolate-saccharide graft reactions. Food Chem., 97: 577-585

Hattori, M., S. Miyakawa, Y. Ohama, H. Kuwamura, T. Yoshida, K. To-o, T. Kuriki and K. Takahashi 2004 Reduced immunogenicity of $\beta$-lactoglobulin by conjugation with acidic oligosaccharides. J. Agri. Food Chem., 52: 4546-4553

Laemmli, U. K. 1970 Cleavage of structural proteins during the assembly of the head of bacteriophage T4. Nature, 227: $680-685$

Mennella, C., V. Marianna, N. Aurora, D. C. Maria Dolores and F. Vincenzo 2006 Glycation of lysine-containing dipeptides. J. Pept. Sci., 12: 291-296

O’Brien, J. 1995 Heat-induced changes in lactose: isomerization, degradation, Maillard browning. In "Heat-induced changes in milk", 2nd ed. ed. by P. F. Fox, IDF., Brussels, pp. 134-170

Shazman, A., S. Mizrahi, U. Cogan and E. Shimoni 2007 Examining for possible non-thermal effects during heating in a microwave oven. Food Chem., 103: 444-453

Simons, S. S. and D. F. Johnson 1976 The structure of the fluo- 
rescent adduct formed in the reaction of $O$-phthalaldehyde and thiols with amines. J. Am. Chem. Soc., 98: 7098-7099 